\title{
EMMPRIN (CD147) as a potential predictor of oral squamous cell carcinoma progression: A study from Pakistan
}

\author{
Rakia Sahaf ${ }^{1 *}$, Nadia Naseem ${ }^{1 \dagger}$, Aman-ur-Rehman $^{2 \dagger}{ }^{+}$, Rabia Anjum ${ }^{1 \dagger}$ and Abdul Hanan Nagi ${ }^{1 \dagger}$ \\ *Correspondence: rakiasahaf@gmail.com \\ CrossMark \\ $\leftarrow$ Click for updates

\begin{abstract}
'These authors contributed equally to this work. 'Department of Morbid Anatomy \& Histopathology/Oral Pathology, University of Health Sciences Lahore, Pakistan. ${ }^{2}$ Department of Histopathology, Sheikh Zayed Hospital Lahore, Pakistan.
\end{abstract}

\begin{abstract}
Background: Oral squamous cell carcinoma (OSCC) is among the frequently reported malignancies in Pakistan having unfavorable prognosis. Extracellular Matrix Metalloproteinase Inducer (EMMPRIN) is a transmembrane glycoprotein that is implicated in tumorigenesis and is recognized as a potential therapeutic target in multiple carcinomas.

Objective: To determine the immuohistochemical expression of EMMPRIN (CD147) in biopsies from OSCC patients in the Pakistani population.

Methods: This descriptive study was conducted in Lahore, Pakistan, comprising 100 OSCC cases presenting, from January 2010 to September 2015. Detailed clinical parameters were recorded. Histological diagnosis \& grade was assessed followed by scoring of CD147 immunoexpression into low (score 0-5) and high (score 6-7). The data were analysed using SPSS 21.0. Pearson Chi square and Fisher Exact test were applied. A P value $\leq$ 0.05 was considered as statistically significant.
\end{abstract}

Results: Histologically, conventional OSCC was the most prevalent subtype (92\%) followed by oral papillary $(6 \%)$ and verrucous $(2 \%)$ carcinomas. Well differentiated carcinomas made most of the tumour burden $(64 \%)$. $60 \%$ carcinomas expressed high score while $40 \%$ showed low expression scores. EMMPRIN expression was significantly associated with the degree of differentiation of the tumour $(\mathrm{P}=0.001)$.

Conclusions: The findings of the current study highlight the significance of EMMPRIN (CD147) expression in relation to cancer progression thus marking its potential for being an attractive target for immunotherapeutic approaches.

Keywords: EMMPRIN (CD 147), oral squamous cell carcinoma (OSCC), immunohistochemistry

\section{Introduction}

Oral squamous cell carcinoma (OSCC) is globally one of the most frequently reported malignant neoplasms, accounting for more than $90 \%$ of oral cancers. In Pakistan, it is the second most common malignancy [1] and comprises $15 \%$ of estimated new cancer cases in this region compared to $3 \%$ detected worldwide [2].

OSCC demonstrates histologically a heterogeneous cell population with differences in the degree of differentiation, invasive and metastatic potential. The mortality and morbidity of OSCC has not changed considerably over the last few decades. Detection of biomarkers implicated in various cancers and the advent of targeted molecular therapies have led to a radical change in the treatment of different tumours.

Extracellular matrix metalloproteinase inducer (EMMPRIN), also known as CD147, was originally identified as a tumour cell membrane protein that induces matrix metalloproteinase (MMP) production from adjacent fibroblasts [3]. It is present both on the tumour and normal cells and it is believed to play major roles in the regulation of different cellular activities. EMMPRIN expression is enhanced in several malignancies as compared to benign and the normal tissues [4]. Overexpression or mutation of EMMPRIN is found in $95 \%$ of the patients with oral SCC [5]. It plays a vital role in the tumorigenesis by promoting invasion, 
angiogenesis, growth and survival of malignant cells because of its association with different proteins involved in various signalling pathways [5].

Recently, EMMPRIN (CD147) has been reported to be a useful diagnostic and prognostic marker as it is involved in various aspects of cancer progression [6].The current study aimed at determining, for the first time in Pakistan, the immuohistochemical expression of EMMPRIN in patients with oral squamous cell carcinoma and to investigate the association of this protein with various clinicopathological parameters of the tumour in our population.

\section{Materials and methods}

This descriptive study was conducted at the Department of Oral Pathology, Lahore, Pakistan. Approval from the institutional ethical review committee was obtained prior to the commencement of the study. A total of 100 biopsies of patients who reported with various histological subtypes and grades of OSCC from both genders and all age groups were included. While patients already on chemo-radio therapy and/or with recurrence were excluded. All selected patients gave written informed consent. Relevant demographic and clinical information were collected from departmental record. The tissues were processed for making paraffin blocks and sections were cut and stained with haematoxylin and eosin for confirmation of the histological diagnosis and grading/ subtyping of tumours. The histological grading of conventional OSCC and papillary OSCC was undertaken according to the criterion laid by Bryne et al. [7] and Velazquez et al. [8] respectively, while oral verrucous carcinoma was taken as well differentiated by default [9].

\section{Immunohistochemistry}

About $4 \mu \mathrm{m}$ thick tissue sections were cut with the help of rotary microtome and mounted on Poly-L-lysine coated slides. Sections were deparaffinised in xylene and rehydrated in graded ethyl alcohol, followed by immersion in citrate buffer solution of $\mathrm{pH} 9.0$ and were put in the hot water bath before staining procedures. Immunohistochemistry was performed using the standard 'Streptavidin biotin Peroxidase' method. Sections were then incubated with mouse lgG1 kappa primary monoclonal CD147 antibody [HIM6] (Bio Legend; USA) with a dilution of 1:25 and DAB chromogen was applied to the sections followed by counterstaining with haematoxylin. Positive (oral mucosa and skin) and negative (omission of primary antibody) controls were run with each batch of 20 histological sections of OSCCs. EMMPRIN (CD147) expression was scored on basis of proportion and intensity of immunolabeling in tumour cell membrane and cytoplasm.

The intensity (qualitative variable) of staining was evaluated as 0 (negative), 1 (weak), 2 (moderate), and 3 (strong). The proportion (quantitative variable) of positive tumour cells was scored as 0 (no labelling or labelling in $<10 \%$ of tumour cells); 1 ( $10 \%$ to $24 \%$ positive cells); 2 ( $25 \%$ to $49 \%$ positive cells); 3 ( $50 \%$ to $74 \%$ positive cells); and 4 ( $75-100 \%$ positive cells). A final score, labelled as a total score (0-7), was given by adding the intensity and the proportion score and was categorized into four groups, where $0-1$, negative staining; 2-3, weak positive $(+1)$; 4-5, moderate positive $(+2)$; and 6-7, strong positive $(+3)$. For statistical analysis, total scores of 0 -5 and 6-7 were considered to be low expression and high expression scores respectively [10].

\section{Statistical analysis}

The data were entered and analysed using SPSS 21.0. Mean \pm S.D were given for quantitative variables and frequencies and percentages were computed for qualitative variables. Pearson Chi square and Fisher Exact test were applied to observe associations between the variables. A $P$ value $\leq 0.05$ was considered as statistically significant.

\section{Results}

Of the 100 OSCC cases, the overall mean age of the patients was $51.28 \pm 15.65$ years with the age range of $25-80$ years. The male to female ratio was 1.3:1 with most cases reported in $5^{\text {th }}$ to $6^{\text {th }}$ decade of life (Table 1 ).

Table 1. Age Distribution with respect to Gender.

\begin{tabular}{|c|c|c|c|c|}
\hline \multirow{2}{*}{$\begin{array}{l}\text { Age } \\
\text { (years) }\end{array}$} & \multicolumn{2}{|c|}{ Gender } & \multirow[t]{2}{*}{ Total (n \%) } & \multirow{2}{*}{$\begin{array}{l}P \text {-value } \\
(\text { n \%) }\end{array}$} \\
\hline & Female (n \%) & Male (n \%) & & \\
\hline $25-40$ & 2 & 24 & 26 & \multirow{4}{*}{$<0.001^{\star}$} \\
\hline $41-60$ & 24 & 26 & 50 & \\
\hline $61-80$ & 16 & 8 & 24 & \\
\hline Total & 42 & 58 & 100 & \\
\hline
\end{tabular}

${ }^{\star}$ Pearson Chi-square test

Variable clinical presentations were recorded in all study cases (Table 2). As regards the site of involvement of oral cavity, occurrence of OSCC was higher on the tongue (40\%) followed by buccal mucosa (34\%) and other sites (Table 2). In females, predominant involvement of tongue was seen (43\%) whereas in males, buccal mucosa was the most commonly involved site (41\%).

In the current study, the most prevalent histological subtype was conventional oral squamous cell carcinoma (92\%). This was followed by oral papillary (6\%) and verrucous (2\%) carcinomas (Table 3). Regarding the histological grades, well differentiated OSCC was the most common presentation in the present study patients (Table 3 ).

In the present study, among the 100 OSCC specimens investigated, all cases were positive for EMMPRIN/CD147 antibody showing cytoplasmic and predominantly membranous staining for the positive tumour cells throughout the entire section. Conversely, in positive control specimens (normal skin and buccal mucosa), EMMPRIN (CD147) expression was localized to the actively differentiating basal epithelial cells (Figure 1). In OSCC, positive EMMPRIN (CD147) immunoreactivity was 
Sahaf et al. Journal of Histology \& Histopathology 2017,

http://www.hoajonline.com/journals/pdf/2055-091X-4-8.pdf

Table 2. Clinical Presentation and Gender Distribution with respect to Site in OSCC.

\begin{tabular}{|c|c|c|c|c|c|c|c|c|c|c|}
\hline \multirow[t]{2}{*}{ Factors } & & \multicolumn{7}{|l|}{ Site } & \multirow{2}{*}{$\begin{array}{l}\text { Total } \\
(\mathbf{n} \%)\end{array}$} & \multirow[t]{2}{*}{$P$ value } \\
\hline & & $\begin{array}{l}\text { Buccal } \\
\text { mucosa } \\
(\mathrm{n} \%)\end{array}$ & $\begin{array}{l}\text { Gingiva } \\
(\mathrm{n} \%)\end{array}$ & $\begin{array}{l}\text { Hard } \\
\text { Palate } \\
(\mathrm{n} \%) \\
\end{array}$ & $\begin{array}{l}\text { Lower } \\
\text { Lip } \\
(\mathbf{n} \%)\end{array}$ & $\begin{array}{l}\text { Sub- mandibular } \\
\text { gland (n \%) }\end{array}$ & $\begin{array}{l}\text { Tongue } \\
\text { (n \%) }\end{array}$ & $\begin{array}{l}\text { Upper } \\
\text { Lip (n \%) }\end{array}$ & & \\
\hline \multirow{4}{*}{$\begin{array}{l}\text { Clinical } \\
\text { Presentation }\end{array}$} & Ulceration & 14 & 0 & 2 & 0 & 4 & 28 & 0 & 48 & \multirow{4}{*}{$<0.001^{\star}$} \\
\hline & Lump & 12 & 4 & 0 & 12 & 2 & 4 & 2 & 36 & \\
\hline & Exophytic mass & 4 & 0 & 0 & 0 & 0 & 4 & 0 & 8 & \\
\hline & White patch & 4 & 0 & 0 & 0 & 0 & 4 & 0 & 8 & \\
\hline \multirow[t]{2}{*}{ Gender } & Female & 10 & 2 & 2 & 4 & 4 & 18 & 2 & 42 & \multirow{2}{*}{$0.123^{x}$} \\
\hline & Male & 24 & 2 & 0 & 8 & 2 & 22 & 0 & 58 & \\
\hline
\end{tabular}

${ }^{\star}$ Fisher exact test

Table 3. Relationship between clinicopathological parameters and histologic subtypes of 0SCC.

\begin{tabular}{|c|c|c|c|c|c|c|}
\hline \multirow[t]{2}{*}{ Factor } & & \multirow[t]{2}{*}{ Total (n\%) } & \multicolumn{3}{|c|}{ HISTOLOGICAL SUBTYPES } & \multirow[t]{2}{*}{$P$-value } \\
\hline & & & $\begin{array}{l}\text { Conventional } \\
\text { OSCC } \dagger(\mathbf{n} \%)\end{array}$ & $\begin{array}{l}\text { Papillary } \\
\text { OSCC } \$(\mathbf{n} \%)\end{array}$ & $\begin{array}{l}\text { Verrucous } \\
\text { Carcinoma(n \%) }\end{array}$ & \\
\hline \multirow[t]{3}{*}{ Age } & $25-40$ years & 26 & 24 & 2 & 0 & \multirow{3}{*}{$0.139^{*}$} \\
\hline & $41-60$ years & 50 & 46 & 4 & 0 & \\
\hline & $61-80$ years & 24 & 22 & 0 & 2 & \\
\hline \multirow[t]{2}{*}{ Gender } & Male & 58 & 54 & 4 & 0 & \multirow{2}{*}{$0.346^{*}$} \\
\hline & Female & 42 & 38 & 2 & 2 & \\
\hline \multirow[t]{7}{*}{ Site } & Buccal mucosa & 34 & 30 & 2 & 2 & \multirow{7}{*}{$0.816^{*}$} \\
\hline & Tongue & 40 & 36 & 4 & 0 & \\
\hline & Lower lip & 12 & 12 & 0 & 0 & \\
\hline & Upper lip & 2 & 2 & 0 & 0 & \\
\hline & Gingiva & 4 & 4 & 0 & 0 & \\
\hline & Hard palate & 2 & 2 & 0 & 0 & \\
\hline & Submandibular gland & 6 & 6 & 0 & 0 & \\
\hline \multirow[t]{4}{*}{ Clinical Presentation } & Ulceration & 48 & 48 & 0 & 0 & \multirow{4}{*}{$<0.001^{\star}$} \\
\hline & Lump & 36 & 36 & 0 & 0 & \\
\hline & White patch & 8 & 8 & 0 & 0 & \\
\hline & Exophytic mass & 8 & 0 & 6 & 2 & \\
\hline \multirow[t]{3}{*}{ Histological Grade } & Well differentiated & 64 & 62 & 0 & 2 & \multirow{3}{*}{$0.001^{\star}$} \\
\hline & Moderately differentiated & 26 & 20 & 6 & 0 & \\
\hline & Poorly differentiated & 10 & 10 & 0 & 0 & \\
\hline
\end{tabular}

${ }^{*}$ Fisher exact test

†Graded by Bryne’s grading system [7]

${ }^{\ddagger}$ Graded in accordance to College of American Pathologists (CAP) protocol [8]

${ }^{\S}$ By default taken as well differentiated [9]

seen ranging from low to strong positive expression. Total score derived from staining intensities and percentages of positive cells, demonstrated strong positive expression (+ 3) of EMMPRIN (CD147) in 60\% cases, moderate positive expression (+2) in $36 \%$ and weak positive expression $(+1)$ was seen in $4 \%$ cases. While categorizing the expression levels into low and high, $60 \%$ analysed cases demonstrated high EMMPRIN expression (Figures 2B and 2C) while $40 \%$ showed low EMMPRIN expression scores (Figure 2A). No case was detected showing negative staining.

EMMPRIN high and low expression scores in different histological grades of OSCC (Table 4) demonstrate that cases of moderate and poorly differentiated OSCC exhibited high expression score more often than well differentiated tumours $(P=0.001)$. However, no significant association between EMMPRIN expression and the other listed clinicopathological variables was seen.

\section{Discussion}

Oral carcinogenesis is a multistep cascade that involves complex molecular pathways in disease progression. Targeting the molecular pathways involved in tumorigenesis remains 


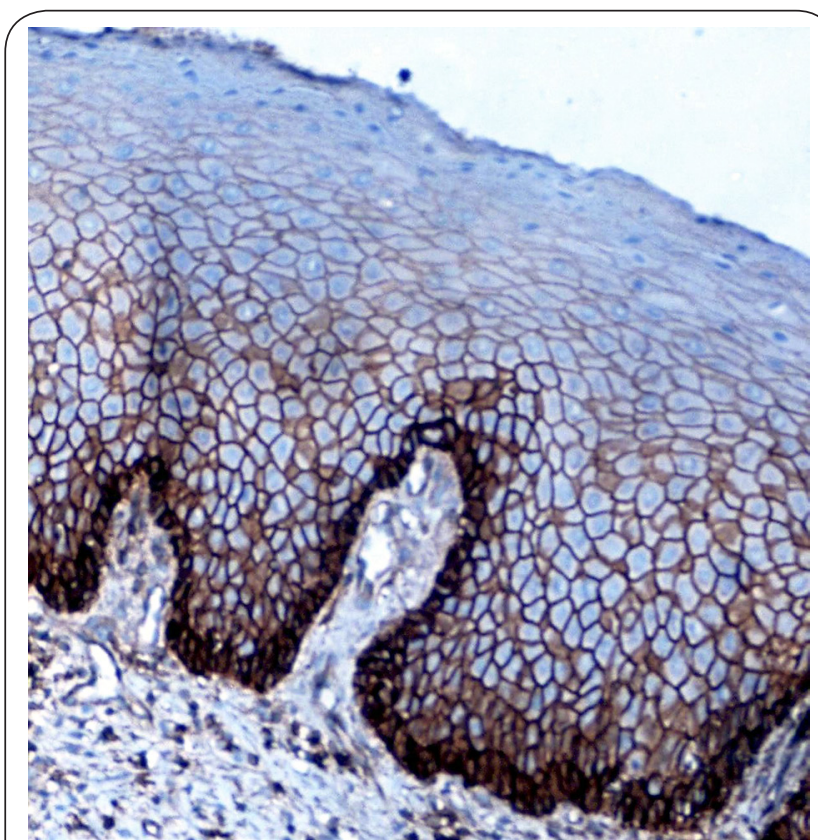

Figure 1. Photomicrograph of Normal oral mucosa showing staining localized to keratinocytic cell membrane with enhanced staining of the basal epithelial cells (EMMPRIN IHC, x200).

the greatest opportunity to halt cancer progression. In the present study, among the 100 OSCC cases evaluated for different clinicopathological variables, the mean age of occurrence (51.28 \pm 15.65 years) is consistent with the study conducted by Rahman et al. [11] with most cases seen in the fifth decade of life.

The gender related findings of the current study (Male: Female ratio, 1.3:1) are also consistent with the local [12] and international studies [13] showing male predominance. In the current study, the commonest presenting complaint was non healing ulcer (48\%) with the tongue being the most frequently affected site (40\%). These finding are in accordance with other studies [14].

As regards the histologic subtypes, conventional OSCC was the most prevalent subtype encountered in the current study (92\%); and this finding is almost universal in all local and international studies. The clinical variables, age, site of tumour, gender and clinical presentation in conventional OSCC are found to be similar to the parameters of OSCC as discussed earlier.

The papillary OSCC was diagnosed in $6 \%$ of the present cases, while Thompson [15] revealed that it constitutes approximately $1 \%$ of all OSCCs. In contrast to the findings of the current study, Bao et al. [16] reported 63.3 years mean age and found the most frequent site to be the gingiva. Most studies have demonstrated that papillary OSCC shows male predilection and presents clinically as an exophytic mass [17], a finding corroborated by the present results.

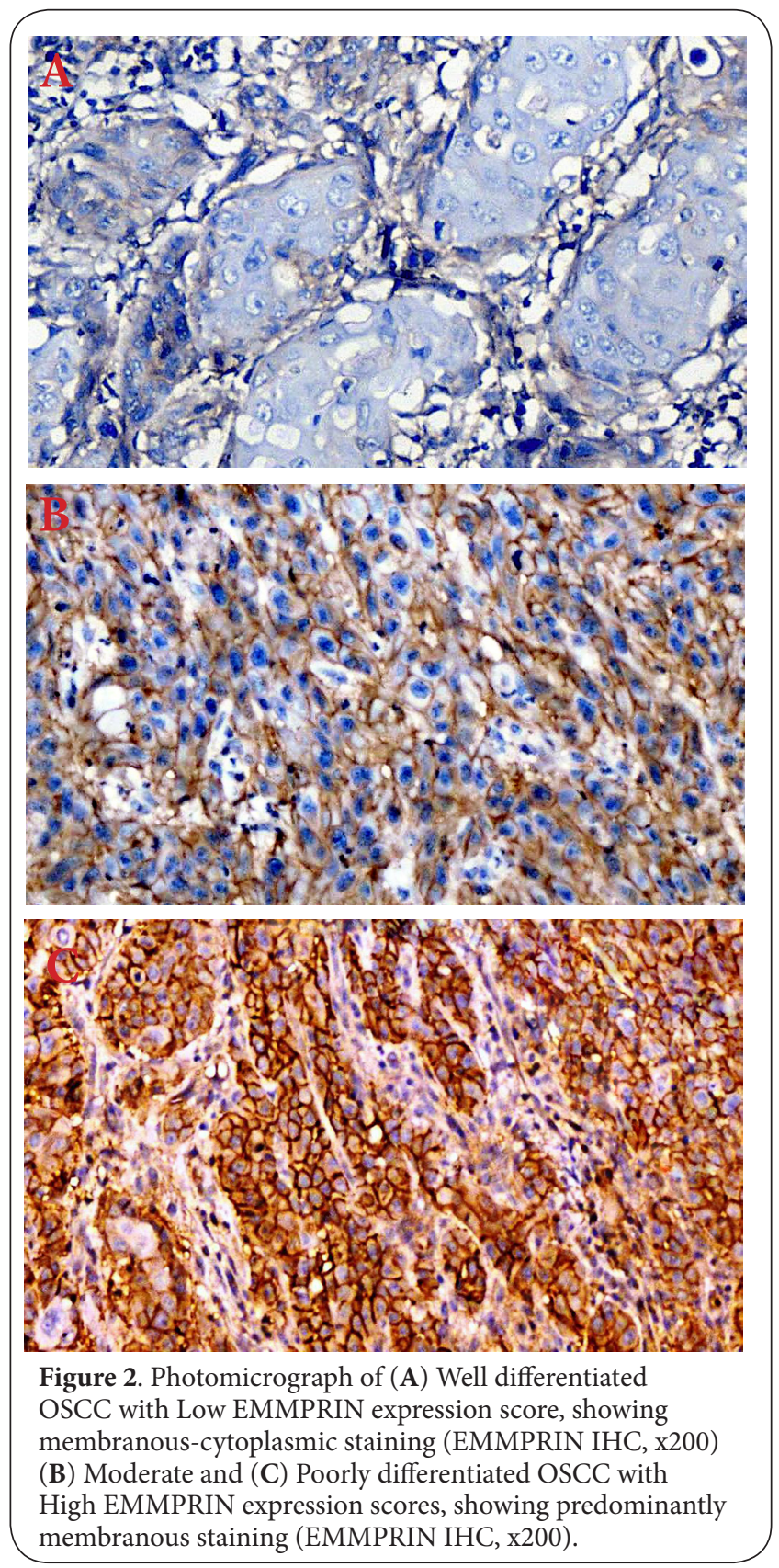

Verrucous carcinoma (VC) accounted for $2 \%$ of the total studied cases of the present study. Neville et al. [18] reported that VC accounts for $1-10 \%$ of all oral squamous cell carcinomas, depending on the local acceptance of smokeless tobacco use. In the current study, VC clinically presented at an age of 65 years as an exophytic mass on the buccal mucosa, which is in accordance with the reviewed literature [19].

As for the histological grade, among the 100 OSCC cases investigated, well differentiated carcinomas made most of the tumour burden (64\%). Among 92 cases of conventional OSCC, most of the cases were well differentiated (67.4\%) followed by moderate and poorly differentiated cases. Comparable 
Sahaf et al. Journal of Histology \& Histopathology 2017, http://www.hoajonline.com/journals/pdf/2055-091X-4-8.pdf

Table 4. Association of EMMPRIN (CD147) expression with different clinicopathological features of OSCC Cases.

\begin{tabular}{|c|c|c|c|c|c|}
\hline \multirow[t]{2}{*}{ Factor } & & \multicolumn{3}{|c|}{ EMMPRIN (CD147) } & \multirow[b]{2}{*}{$P$-value } \\
\hline & & Total (n \%) & $\begin{array}{l}\text { Low expression Score } \\
\text { n (\%) }\end{array}$ & $\begin{array}{l}\text { High expression } \\
\text { Score } \mathbf{n}(\%)\end{array}$ & \\
\hline \multirow[t]{3}{*}{ Age } & $25-40$ years & 26 & $6(23)$ & $20(77)$ & \multirow{3}{*}{$0.04^{*}$} \\
\hline & 41-60 years & 50 & $26(52)$ & $24(48)$ & \\
\hline & $61-80$ years & 24 & $8(33)$ & $16(67)$ & \\
\hline \multirow[t]{2}{*}{ Gender } & Male & 58 & $20(34.5)$ & $38(65.5)$ & \multirow[b]{2}{*}{$0.19^{\star}$} \\
\hline & Female & 42 & $20(48)$ & $22(52)$ & \\
\hline \multirow[t]{7}{*}{ Site } & Buccal mucosa & 34 & $8(23.5)$ & $26(76.5)$ & \multirow{7}{*}{$0.01 \dagger$} \\
\hline & Tongue & 40 & $22(55)$ & $18(45)$ & \\
\hline & Gingiva & 4 & $0(0)$ & $4(100)$ & \\
\hline & Hard palate & 2 & $2(100)$ & $0(0)$ & \\
\hline & Lower lip & 12 & $6(50)$ & $6(50)$ & \\
\hline & Upper lip & 2 & $0(0)$ & $2(100)$ & \\
\hline & Sub-mandibular gland & 6 & $2(33)$ & $4(67)$ & \\
\hline \multirow{4}{*}{$\begin{array}{l}\text { Clinical } \\
\text { Presentation }\end{array}$} & Ulceration & 48 & $22(46)$ & $26(54)$ & \multirow{4}{*}{$0.54 \dagger$} \\
\hline & Swelling/lump & 36 & $12(33)$ & $24(67)$ & \\
\hline & White patch & 8 & $2(25)$ & $6(75)$ & \\
\hline & Exophytic mass & 8 & $4(50)$ & $4(50)$ & \\
\hline \multirow{3}{*}{$\begin{array}{l}\text { Histological } \\
\text { subtype }\end{array}$} & Conventional OSCC & 92 & $36(39)$ & $56(61)$ & \multirow[t]{3}{*}{$0.27 \dagger$} \\
\hline & Papillary OSCC & 6 & $4(67)$ & $2(33)$ & \\
\hline & Oral Verrucous carcinoma & 2 & $0(0)$ & $2(100)$ & \\
\hline \multirow{3}{*}{$\begin{array}{l}\text { Histological- } \\
\text { Grade }\end{array}$} & Well Differentiated & 64 & $34(53)$ & $30(47)$ & \multirow{3}{*}{$0.001^{\star}$} \\
\hline & Moderately Differentiated & 26 & $2(23)$ & $20(77)$ & \\
\hline & Poorly Differentiated & 10 & $0(0)$ & $10(100)$ & \\
\hline
\end{tabular}

*Pearson Chi-square test ${ }^{\dagger}$ Fisher exact test.

results were seen in local [12] and international studies [20].

In the present study, verrucous carcinoma was taken as well differentiated by default [9].

Regarding papillary OSCC, all the cases in the present study were graded as moderately differentiated. However, in the study conducted on gingival papillary SCC, Fitzpatrick et al. [21] demonstrated most of the cases as either well or moderately-well differentiated (88\%) while $12 \%$ of the cases were graded as moderate or moderately-poor. Such variations in OSCC could be attributed to ethnic and racial disparities and can be closely related to prognosis.

In the current study, EMMPRIN immunohistochemical expression was evaluated in OSCC cases presenting in our part of the world. All studied cases of OSCC (100\%) were positive for CD 147 antibody with EMMPRIN (CD147) immunoexpression seen predominantly in tumour cell membrane (Figure 2B) and also in cytoplasm (Figure 2A) of some cases. This is in accordance with the immunohistochemical studies done by Piao et al. [10] in salivary duct carcinoma. Cytoplasmic and membranous staining pattern acquired by tumour cells may be attributed to cytoplasmic and membranous domain of EMMPRIN (CD147), as described by lacono et al. [22].

According to the immunostaining results of the present study, more than half of the OSCC cases (60\%) were catego- rized as having high EMMRIN expression score and (40\%) cases showed low EMMPRIN expression scores. No case was detected showing negative staining. Similar to these findings, Monteiro et al. [5] showed positive EMMPRIN (CD147) immunoreactivity in all examined OSCC cases with high expression in $75.7 \%$ of the cases.

However, the positive control specimens (normal skin and buccal mucosa), investigated in the present study, depicted no strong positive staining with enhanced EMMPRIN staining in the basal cell layer suggesting the proliferative potential of EMMPRIN (CD147) (Figure 1). This is in compliance with the findings of Huang et al. [23], who demonstrated a significantly higher expression in cancer cells compared with adjacent non-cancerous epithelium in tongue squamous cell carcinomas. Even though EMMPRIN (CD147) showed weak positivity in normal epithelial cells, it might be representative of a physiological role in tissue remodelling under specific conditions [24].

In the present study, no significant association was instituted between EMMPRIN (CD147) immuno-histochemical expression and different clinical parameters of OSCC (age, gender, site, clinical presentation) which is consistent with other studies $[\mathbf{5}, \mathbf{2 5}]$. Moreover, relation between EMMPRIN expression and histologic subtypes of OSCC was also found 
to be statistically insignificant $(P>0.05)$. This can be due to varying morphologic features and biological behaviour of different histological subtypes. However, we found significant association ( $P=0.001$ ) between the low and high EMMPRIN scores and histological grades of OSCC, where moderate $(77 \%)$ and poorly differentiated (100\%) OSCCs exhibited high expression score as compared to well differentiated tumours (47\%). Studies focused on EMMPRIN high and low score $[\mathbf{5 , 2 5}]$ are concordant to the findings of the present study demonstrating significant association of EMMPRIN expression with histological grades of OSCC ( $P=0.002 \& 0.005$ respectively).

In contrast to these findings, the study conducted by Huang et al. [23] on tongue squamous cell carcinoma reported no significant association between EMMPRIN (CD147) expression and histologic grades $(P=0.962)$. These discrepancies suggest different grouping and statistical methods and might be largely attributable to different governing mechanisms of EMMPRIN (CD147) expression in cells of different origin.

Since EMMPRIN (CD147) is a multifunctional biological molecule and an important factor in epithelial connective tissue interactions, it is likely to play an important role in OSCC progression. Previously, Baba et al. [26] reported that blocking CD147 using monoclonal antibody induces cell death in cancer cells of colon cancer. Thus EMMPRIN (CD147) might be considered as an objective and effective marker to predict the invasion and prognosis of OSCC.

To our knowledge, no such documented immunohistochemical study elaborating the role of Extracellular Matrix Metalloproteinase Inducer (EMMPRIN) in OSCC has been conducted in Pakistan or any other South Asian country so there is a lack of data for comparison in this regard. Further studies on larger sample size are required to explicate the molecular and genetic mechanisms to assess the tumour related effects of EMMPRIN (CD147). Better understanding of the molecular mechanisms causing dysregulated growth and OSCC progression may provide a basis for discovering new treatment modalities and can be useful in the development of new molecular therapies and targeting tools. This area of future research undoubtedly will further improve our understanding of OSCC carcinogenesis and the role played by EMMPRIN (CD147).

\section{Conclusion}

EMMPRIN (CD147) protein is widely but variably expressed in all OSCC cases in our population, with a significant association with the degree of differentiation of the tumour.

The findings of the current study highlight the significance of EMMPRIN (CD147) expression in relation to cancer progression thus marking its potential for being an attractive target for immunotherapeutic approaches.

\section{List of abbreviations}

CAP: College of American Pathologists

CD: Cluster differentiation

DAB: Diaminobenzidine
EMMPRIN: Extracellular Matrix Metalloproteinase Inducer

Ig: Immunoglobulin

IHC: Immunohistochemistry

MMPs: Matrix metalloproteinases

OSCC: Oral Squamous Cell Carcinoma

$\mathrm{pH}$ : Power of Hydrogen

SCC:Squamous Cell Carcinoma

SPSS: Statistical Package for the Social Sciences

VC: Verrucous carcinoma

\section{Competing interests}

The authors declare that they have no competing interests. Authors' contributions

\begin{tabular}{|l|c|c|c|c|c|}
\hline Authors' contributions & RS & NN & AR & RA & AHN \\
\hline Research concept and design & $\checkmark$ & $\checkmark$ & -- & -- & $\checkmark$ \\
\hline Collection and/or assembly of data & $\checkmark$ & -- & $\checkmark$ & -- & -- \\
\hline Data analysis and interpretation & $\checkmark$ & $\checkmark$ & -- & $\checkmark$ & $\checkmark$ \\
\hline Writing the article & $\checkmark$ & -- & -- & -- & -- \\
\hline Critical revision of the article & $\checkmark$ & $\checkmark$ & -- & -- & $\checkmark$ \\
\hline Final approval of article & $\checkmark$ & $\checkmark$ & $\checkmark$ & $\checkmark$ & $\checkmark$ \\
\hline Statistical analysis & $\checkmark$ & $\checkmark$ & -- & -- & $\checkmark$ \\
\hline
\end{tabular}

\section{Acknowledgement}

The authors acknowledge the encouragement extended by the Vice Chancellor of University of Health Sciences, Lahore Pakistan. Also, to Mr. Sameer Anjum and Mr. Ghulam Rasool, the laboratory staff of Morbid Anatomy \& Histopathology Department, University of Health Sciences, Lahore, Pakistan for their technical and logistic support.

\section{Publication history}

EIC: Gaetano Giuseppe Magro, University of Catania, Italy. Received: 07-May-2017 Final Revised: 28-Jun-2017

Accepted: 10-Jul-2017 Published: 22-Jul-2017

\section{References}

1. Cancer Registry and Clinical Data Management (CRCDM). Shaukat Khanum Memorial Cancer Hospital and Research Center (SKMCH \& RC). 2014. | Website

2. Ferlay J, Shin HR, Bray F, Forman D, Mathers $C$ and Parkin DM. Estimates of worldwide burden of cancer in 2008: GLOBOCAN 2008. Int J Cancer. 2010; 127:2893-917. | Article | PubMed

3. Nabeshima K, Lane WS and Biswas C. Partial sequencing and characterization of the tumor cell-derived collagenase stimulatory factor. Arch Biochem Biophys. 1991; 285:90-6. | Article | PubMed

4. Riethdorf S, Reimers N, Assmann V, Kornfeld JW, Terracciano L, Sauter G and Pantel K. High incidence of EMMPRIN expression in human tumors. Int J Cancer. 2006; 119:1800-10. | Article | PubMed

5. Monteiro LS, Delgado ML, Ricardo S, Garcez F, do Amaral B, Pacheco JJ, Lopes $C$ and Bousbaa H. EMMPRIN expression in oral squamous cell carcinomas: correlation with tumor proliferation and patient survival. Biomed Res Int. 2014; 2014:905680. | Article | PubMed Abstract | PubMed FullText

6. Zheng HC, Takahashi H, Murai Y, Cui ZG, Nomoto K, Miwa S, Tsuneyama $\mathrm{K}$ and Takano $\mathrm{Y}$. Upregulated EMMPRIN/CD147 might contribute to growth and angiogenesis of gastric carcinoma: a good marker for local invasion and prognosis. Br J Cancer. 2006; 95:1371-8. | Article | PubMed Abstract I PubMed FullText

7. Bryne M. Is the invasive front of an oral carcinoma the most important area for prognostication? Oral Dis. 1998; 4:70-7. | Article | PubMed

8. Velazquez EF, Amin MB, Epstein JI, Grignon DJ, Humphrey PA, Pettaway CA, Renshaw AA, Reuter VE, Srigley JR and Cubilla AL. Protocol for the examination of specimens from patients with carcinoma of the penis. Arch Pathol Lab Med. 2010; 134:923-9. | Article | PubMed 
Sahaf et al. Journal of Histology \& Histopathology 2017,

9. Cardesa A and Zidar N. Verrucous Carcinoma. In: Barnes L, Eveson JW, Reichart P and Sidransky D (Eds.), Pathology and Genetics of Head and Neck Tumours. Lyon, France: IARC Press. 2005; 122.

10. Piao S, Zhao S, Guo F, Xue J, Yao G, Wei Z, Huang Q, Sun Y and Zhang B. Increased expression of CD147 and MMP-9 is correlated with poor prognosis of salivary duct carcinoma. J Cancer Res Clin Oncol. 2012; 138:627-35. | Article | PubMed

11. Rahman SS, Sarker MK, Khan MHA, Biswas SS and Saha MM. Clinical profile of oral squamous cell carcinoma patients attending a tertiary care hospital. Bang. Med. J. Khulna. 2014; 47:3-6.

12. Khaleel ME, Raza A, Ehsan A, Masood R and Javed M. Clinicopathological spectrum of oral squamous cell carcinoma at a public sector health facility. Biomedica. 2015; 31:21-26.

13. Hernandez-Guerrero JC, Jacinto-Aleman LF, Jimenez-Farfan MD, MacarioHernandez A, Hernandez-Flores F and Alcantara-Vazquez A. Prevalence trends of oral squamous cell carcinoma. Mexico City's General Hospital experience. Med Oral Patol Oral Cir Bucal. 2013; 18:e306-11. | Article | PubMed Abstract | PubMed FullText

14. Pires FR, Ramos AB, Oliveira JB, Tavares AS, Luz PS and Santos TC. Oral squamous cell carcinoma: clinicopathological features from 346 cases from a single oral pathology service during an 8-year period. J Appl Oral Sci. 2013; 21:460-7. | Article | PubMed Abstract | PubMed FullText

15. Thompson LDR. Squamous cell carcinoma variants of the head and neck. Curr. Diagn. Pathol. 2003; 9:384-96. | Article

16. Bao Z, Yang X, Shi L, Feng J, Liu W and Zhou Z. Clinicopathologic features of oral squamous papilloma and papillary squamous cell carcinoma: a study of 197 patients from eastern China. Ann Diagn Pathol. 2012; 16:454-8. | Article | PubMed

17. Cardesa A, Zidar N, Nadal A and Ereno C. Papillary Squamous Cell Carcinoma. In: Barnes L, Eveson JW, Reichart P and Sidransky D (Eds.), Pathology and Genetics of Head and Neck Tumours. Lyon, France: IARC Press. 2005; 126.

18. Neville BW, Damm DO, Allen CM and Chi AC. Oral and Maxillofacial pathology. 4th ed. Philadelphia: Saunders. 2016.

19. Kamala KA, Sankethguddad S, Sujith SG. Verrucous carcinoma of oral cavity - a case report with review of literature. Int. J. Health Sci. Res. 2015; 5:330-4.

20. Krishna A, Singh RK, Singh S, Verma P, Pal US and Tiwari S. Demographic risk factors, affected anatomical sites and clinicopathological profile for oral squamous cell carcinoma in a north Indian population. Asian Pac J Cancer Prev. 2014; 15:6755-60. | Article | PubMed

21. Fitzpatrick SG, Neuman AN, Cohen DM and Bhattacharyya I. Papillary variant of squamous cell carcinoma arising on the gingiva: 61 cases reported from within a larger series of gingival squamous cell carcinoma. Head Neck Pathol. 2013; 7:320-6. | Article | PubMed Abstract | PubMed FullText

22. lacono KT, Brown AL, Greene MI and Saouaf SJ. CD147 immunoglobulin superfamily receptor function and role in pathology. Exp Mol Pathol. 2007; 83:283-95. | Article | PubMed Abstract | PubMed FullText

23. Huang $Z$, Huang $H$, Li H, Chen W and Pan C. EMMPRIN expression in tongue squamous cell carcinoma. J Oral Pathol Med. 2009; 38:518-23. | Article | PubMed

24. DeCastro R, Zhang Y, Guo H, Kataoka H, Gordon MK, Toole B and Biswas G. Human keratinocytes express EMMPRIN, an extracellular matrix metalloproteinase inducer. J Invest Dermatol. 1996; 106:1260-5. I Pdf I PubMed

25. Ahmed EM and Farag AS. Expression of EMMPRIN/CD147 and Ki-67 in oral squamous cell carcinoma: An immunohistochemical study. J. Am. Sci. 2014; 10:241-9.

26. Baba $M$, Inoue $M$, Itoh $K$ and Nishizawa Y. Blocking CD147 induces cell death in cancer cells through impairment of glycolytic energy metabolism. Biochem Biophys Res Commun. 2008; 374:111-6. | Article | PubMed

\section{Citation:}

Sahaf R, Naseem N, Rehman A-u, Anjum R and Nagi AH. EMMPRIN (CD147) as a potential predictor of oral squamous cell carcinoma progression: A study from Pakistan. J Histol Histopathol. 2017; 4:8. http://dx.doi.org/10.7243/2055-091X-4-8 